\title{
INITIAL TRAINING OF FUTURE EDUCATION PROFESSIONALS: ARE YOU PREPARED FOR INCLUSION?
}

\author{
Pérez-García, Purificación (mpperez@ugr.es)* \\ Morales-Ocaña, Amelia (amoc@ugr.es)* \\ Martín-Romera, Ana (amromera@ugr.es)* \\ García-Martínez, Inmaculada (igmartinez@ugr.es)*
}

*Universidad de Granada. Departamento de Didáctica y Organización Escolar. Facultad de Ciencias de la Educación. Campus Universitario de Cartuja, s/n. 18071 Granada (España)

https://eera-ecer.de/ecer-programmes/conference/23/contribution/45140/

\begin{abstract}
There is no doubt that we are training our future professionals academically, responding to the curricula designed for such a profession. But the question is whether we are educating them in terms of the responsibility and commitment both to the profession and to the students they have to train.
\end{abstract}

The objective of this research work is to identify the attitude of future professionals toward professional ethics, that is, the attitude of those professionals who will work in an educational centre: teachers, pedagogues, and educational psychologists. In addition, we aimed to find out which are the most significant characteristics of being a good professional.

In our research we adopted the descriptive method and for data collection we used an attitude scale. We used the one designed by Hirsch (2005) entitled "Scale of Attitudes on Professional Ethics", obtaining satisfactory indicators of reliability and validity.

Our sample was composed of the students of the last year of four degrees. It was representative with a 95\% confidence level, and 452 students participated. To calculate this we applied simple random sampling, considering the finite population. Of the total sample, $30.8 \%$ was represented by students from the degree of Infant Education, 20.5\% by Primary Education, $22.1 \%$ were studying Pedagogy and $25.3 \%$ of the sample was from Psychopedagogy.

Our final conclusion is that we do not wish to make the participating students more ethical, but rather that they are able to think ethically about their professional performance. While there is consciousness about ethics, it is very necessary to think more deeply about them, because all students should have been in agreement an ethical attitude.

The future education professionals must be able to think ethically about their professional performance. Only then, we will be able to guarantee their commitment to inclusion, because inclusion is an attitude to the teacher. 
KEYWORDS: initial training, professional ethics, inclusion.

\section{GENERAL DESCRIPTION}

The initial training of professionals dedicated to education is a priority issue on which both academic authorities and policies must concentrate their efforts. Those students who eventually obtain their graduate degree in the faculties of education will be the future trainers of the future citizens of a country. The question is immediate: what kind of training is being taught in these university centres?

There is no doubt that we are training our future professionals academically, responding to the curricula designed for such a profession. But the question is whether we are educating them in terms of the responsibility and commitment both to the profession and to the students they have to train. We do not doubt the knowledge or the aptitude that, without doubt, will be acquired, but what about the attitude? In which study plan is responsibility or commitment contemplated, in which subject, in which skill? Inclusion depends on attitude.

Amongst the Tuning general skills (Villa, Auzmendi and Bezanilla, 2002) that are common to any European university degree, we can find ethical commitment. We understand that students must "know" how to carry out their profession (that is, know how to teach to read, to write, to live in society), but also - and not least - they must "want to carry it out". Knowing the ethical code of their profession with the commitments that it entails would facilitate and help to achieve it.

But the situation of "wanting to carry it out" is in danger. It would require a greater presence of ethics and professional ethics in the curriculum that trains future educators of society.

In the study cited by García, Jover and Escámez (2010) by Jover, Fenández-Salinero and Ruiz (2005), we have been struck by the fact that personal competence in "ethical commitment" is the primary skill for Pedagogues and Social Educators, while in Primary Education it is put in sixth place and in Infant Education it is eighth. What can we expect?

The studies by Conklin and Hughes (2016) that address social justice from initial training are interesting; as are those of Maxwell, Tremblary-Laprise, Filion, Boon, Daly, Hoven, Heilbronn, Lenselink and Walters (2016) that present the ethical challenges in current education; and of particular interest are the works of Chesnut and Cullen (2014) who confirm that future teachers with more emotional awareness are the ones that show the highest commitment rate. So, what is the direction of the initial training to which we must go towards?

The objective of this research work is to identify the attitude of future professionals toward professional ethics, that is, the attitude of those professionals who will work in an educational centre: teachers, pedagogues, and educational psychologists. In addition, we aimed to find out which are the most significant characteristics of being a good professional. 


\section{METHODOLOGY}

The inclusion criteria for participating in the study were to be enrolled in a Practicum. In this part of the course students are assigned to an educational centre to do internships and are for four months in daily contact with students and teachers.

Both in the degree of Infant and Primary Education, this subject of 44 credits was divided into the third and fourth year courses, unlike the degrees of Pedagogy (24 credits) or Psychopedagogy (12 credits) where the work placements are scheduled for the final year.

The population of this study was limited to the students who were in their final year of study and who were enrolled in the Practicum of Infant Education, Primary Education, Pedagogy and Psychopedagogy, resulting in a total of 1157 students. We were interested in the opinion of the students who were immersed in the educational reality of the classrooms.

Our sample was composed of the students of the last year of these four degrees. It was representative with a 95\% confidence level, and 452 students participated. To calculate this we applied simple random sampling, considering the finite population (Tagliacarne, 1968). Of the total sample, $30.8 \%$ was represented by students from the degree of Infant Education, $20.5 \%$ by Primary Education, $22.1 \%$ were studying Pedagogy and $25.3 \%$ of the sample was from Psychopedagogy.

In our research we adopted the descriptive method (Cohen \& Manion, 1990) and for data collection we used an attitude scale (McMillan \& Schumacher, 2005). We used the one designed by Hirsch (2005) entitled "Scale of Attitudes on Professional Ethics" that has been applied in the Spanish and Mexican population, obtaining satisfactory indicators of reliability and validity. This scale is characterized by having three parts: in the first, demographic data were collected (sex, age, academic level, occupation, university, and career); in the second, an open question was formulated asking about the 5 most significant traits needed to be a good professional; and in the third, 55 statements were presented on which the agreement or disagreement of the students had to be expressed through a Likert-type scale, where 1 indicated partial disagreement, 2 disagreement, 3 neither in favour or against, 4 partial agreement, and 5 complete agreement.

\section{RESULTS}

The results revealed the attitude of the graduates towards professional ethics, as well as what they believed to be the most important characteristics of a good professional.

The attitudes on which the students of the four degrees were completely in agreement were: that they would like to deal with professionals who took into account their professional errors, with $82.8 \%$ adopting this stance; and that updating knowledge was essential to be a good professional $(80 \%)$.

On the other hand, they expressed disagreement with the fact that as long as science and technology continued to advance, it was not necessary to worry about its consequences $(41.3 \%)$; that it was not necessary to know and practice the values of the profession to be able to exercise it $(43.5 \%)$; or that their primary interest in carrying out their profession was to earn money and prestige $(48 \%)$. 
Amongst the characteristics, the most notable were, in order of importance: responsibility, commitment, empathy, vocation, training and being competent.

We noticed that statements appearing in the questionnaire related to ethical competence did not achieve unanimous agreement. We refer to aspects such as responsibility, honesty, professional and personal ethics, actions with the notion of providing a service to society, respect, or actions according to moral principles and professional values.

On the other hand, when asked about professional characteristics, the first was taking responsibility. This suggested to us that we imagine one thing when we were thinking of possible traits, and another thing, what we have been able to recognize when we read a proposition related to professional reality.

Our final conclusion is that we do not wish to make the participating students more ethical, but rather that they are able to think ethically about their professional performance. Only then will we have guaranteed their commitment to inclusion.

\section{REFERENCES}

Chesnut, S. R., \& Cullen, T. A. (2014). Effects of Self-Efficacy, Emotional Intelligence, and Perceptions of Future Work Environment on Preservice Teacher Commitment. The Teacher Educator, 49(2), 116-132.

Cohen, L., \& Manion, L. (1990). Métodos de investigación educativa. Madrid: La Muralla.

Conklin, H. G., \& Hughes, H. E. (2016). Practices of Compassionate, Critical, JusticeOriented Teacher Education. Journal of Teacher Education, 67(1), 47-60.

García, R., Jover, G. y Escámez, J. (2010). Ética profesional docente. Madrid: Síntesis.

Hirsch, A. (2005). Construcción de una escala de actitudes sobre ética profesional. Revista Electrónica de Investigación Educativa, 7 (1), 1-16.

Maxwell, B., Tremblay-Laprise, A.-A., Filion, M., Boon, H., Daly, C., van den Hoven, M., Heilbronn, R., Lenselink, M.m \& Walters, S. (2016). A Five-Country Survey on Ethics Education in Preservice Teaching Programs. Journal of Teacher Education, 67(2), 135.

Mcmillan, J., \& Schumacher, S. (2005). Investigación educativa. Madrid: Pearson.

Tagliacarne, G. (1968). Técnica y práctica de la investigación de mercado. Barcelona: Ariel.

Villa, A., Auzmendi, E. y Bezanilla, M.J. (2002): Estudio sobre las competencias en el ámbito universitario europeo. Bilbao: Universidad de Deusto (inédito). 